\title{
Commentary: What can be learned from a case report, or the importance of a well-rounded education
}

\author{
Petros V. Anagnostopoulos, MD
}

\footnotetext{
From the Division of Pediatric Cardiothoracic Surgery, Department of Surgery, The American Family Children's Hospital, The University of Wisconsin Hospital and Clinics, Madison, Wis.

Disclosures: Author has nothing to disclose with regard to commercial support.

Received for publication July 16, 2019; accepted for publication July 17, 2019; available ahead of print Aug 14, 2019.

Address for reprints: Petros V. Anagnostopoulos, MD, American Family Children's Hospital, H4/358, Clinical Sciences Center, 600 Highland Ave, Madison, WI 53792 (E-mail: petros@ surgery.wisc.edu).

J Thorac Cardiovasc Surg 2020;159:e343

$0022-5223 / \$ 36.00$

Copyright (C) 2019 by The American Association for Thoracic Surgery

https://doi.org/10.1016/j.jtcvs.2019.07.023
}

Quadricuspid aortic valves (QAVs) are very rare but have been well described since the early 1970s. ${ }^{1}$ Even less recognized but documented is the association of QAVs with a potential congenital structural aortopathy. In the largest series of QAVs to date, $42 \%$ of patients had ascending aortic diameters greater than or equal to $4 \mathrm{~cm} .{ }^{2}$ Most patients with QAVs present with aortic insufficiency, aortic stenosis, or a combination of these. In this issue of the Journal, $\mathrm{Xu}$ and associates $^{3}$ report on a 35-year-old woman who presented with a QAV associated with a ruptured sinus of Valsalva aneurysm. A tricuspidization procedure was performed, with resection of the smaller ruptured right anterior sinus of Valsalva with the associated cusp, with a great clinical outcome. Time will tell whether this will lead to a durable long-term result. Although the technique of tricuspidization is well described in QAVs, it was first applied in truncus arteriosus repair. ${ }^{4}$ Information regarding the longterm outcomes after these repairs in truncus arteriosus exists in the congenital literature.

This interesting report underscores the importance of well-rounded surgical training and education, with exposure to complex repair techniques of different acquired and congenital heart pathologies. One simply never knows when the patient will show up who is a great candidate for an unusual repair technique that uses principles that have been described in a totally different setting. This becomes ever more important as trainees are asked to master

\section{References} 623-6. 159:e341-2. 2013;44:813-20.

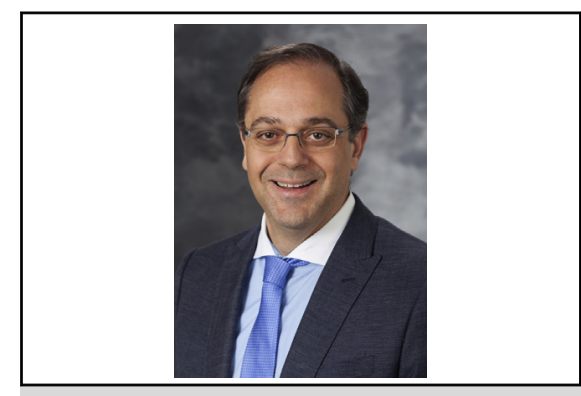

Petros V. Anagnostopoulos, MD

Central Message

A well-rounded training program that exposes trainees to a breadth of experience may come in handy when coming across a lesion that requires an unusual repair.

See Article page e341.

new technologies or to focus on a niche in adult cardiac surgery to remain competitive in the marketplace. Such subspecialty focus typically occurs at the expense of hands-on time and exposure to congenital heart surgery.

1. Hurwitz LE, Roberts WC. Quadricuspid semilunar valve. Am J Cardiol. 1973;31

2. Idrees JJ, Roselli EE, Arafat A, Johnston DR, Svensson LG, Sabik JF III, et al Outcomes after repair or replacement of dysfunctional quadricuspid aortic valve. J Thorac Cardiovasc Surg. 2015;150:79-82.

3. Xu M, Song L, Xiao H, Tao L. Surgical repair of quadricuspid aortic valve associated with ruptured sinus of Valsalva aneurysm. J Thorac Cardiovasc Surg. 2020;

4. Imamura M, Drummond-Webb JJ, Sarris GE, Mee RB. Improving early and intermediate results of truncus arteriosus repair: a new technique of truncal valve repair. Ann Thorac Surg. 1999;67:1142-6.

5. Myers PO, Bautista-Hernandez V, del Nido PJ, Marx GR, Mayer JE, Pigula FA, et al. Surgical repair of truncal valve regurgitation. Eur J Cardiothorac Surg. 